\title{
This time it's personal
}

\author{
The next head of the US National Human Genome Research Institute will need to be equipped to deal with \\ the scientific, political and societal challenges presented by the burgeoning era of personal genomics.
}

O n 28 May, Francis Collins announced that he is stepping down after 15 years as head of the US National Human Genome Research Institute (NHGRI), where he helped lead the international effort to sequence the entire human genetic code (see page 710). His departure is an opportunity to take stock of his legacy and to contemplate the future of the institute he leaves at a crossroads in its existence.

Collins took up his post in 1993, four years before the NHGRI became a separate branch of the National Institutes of Health (NIH) in Bethesda, Maryland. He proved to have a rare combination of political acumen, scientific talent and administrative skill - abilities that allowed him to steer the institute through numerous challenges and reinventions while remaining about as well-liked as it's possible for an institute director to be.

In the 1990s, for example, successful completion of the public arm of the Human Genome Project was in doubt until Collins rallied its members to respond to a challenge led by Craig Venter, a former NIH scientist who was mounting a sequencing effort for commercial purposes. After the genome project was successfully concluded in 2003, some in Washington began asking whether the NHGRI was still needed. Collins made the case - rightly - that the post-genomic era would be even more exciting and challenging than the race to sequence the genome. He and the NHGRI helped prove that by launching a variety of follow-on efforts, including the International HapMap Project, ENCODE (the Encyclopedia of DNA Elements) and, most recently, the 1,000 Genomes Project - an attempt to create an atlas of human genetic variation in unprecedented detail.

Those initiatives have been possible because of technological improvements that dramatically cut the cost of sequencing - improvements for which Collins deserves considerable credit, as he made them funding priorities. The lower costs have accelerated efforts worldwide to clarify the genetic basis of evolution by filling

out the 'tree of life'; more than 100 non-human species have been or are now being sequenced.

Collins also deserves credit for making the ethical, legal and social issues of genomics a high priority at the NHGRI. He says he is particularly satisfied with recent passage through Congress of the Genetic Information Nondiscrimination Act, for which he had long been a passionate advocate. Certainly the passage was timely: cheaper sequencing has ushered in a new era of 'personal genomics', in which companies are offering all manner of tests that claim to reveal a person's susceptibility to conditions such as Alzheimer's disease.

Although Collins says he has no concrete plans for after he steps down on 1 August, speculation is rife that

"The National Human Genome Research Institute may become more of a target for politicians who feel it has run its course." he could serve as NIH director or White House science adviser in the next presidential administration. In the meantime, the future of the NHGRI is more cloudy than his own. The funding situation at the NIH has been gloomy for years, with flat budgets stifling many potentially worthy projects. And with Collins gone, the NHGRI may become more of a target for politicians who feel it has run its course.

Ideally, then, Collins's successor will display both his scientific and political skills. He or she will have to continue to pursue ambitious new projects on the scale of 1,000 Genomes. At the same time, the new director will have to ensure that the implications and applications of those projects are fully explained to all concerned, from the medical profession and insurance companies to politicians and the public. Genomics is now at a point where the science and technology are moving much faster than society's ability to assimilate and make sense of the information. Bridging this gap - a task at which Collins worked very hard - will be his successor's major challenge.

\section{On the campaign trail}

It is less specific policies and more the approach to science that will distinguish the next US president.

P rimary season in the US presidential race is finally over. As the dust settles, it remains to be seen how much the protracted battle between Senators Barack Obama and Hillary Clinton has hurt the Democratic party, but for now politicians of all stripes are regrouping and strategizing about how to win the election.

Those who believe that science and technology issues should be at the forefront of the campaign agenda have so far been disappointed.
The notion of a 'science debate' - itself debatable (see Nature 451, $605 ; 2008)$ - has fizzled out. Pleas for the candidates to address research issues seem largely to have fallen on deaf ears.

Yet there can be little doubt that the next US administration will be more science-friendly than the present one. Both of the expected nominees, Obama and Republican Senator John McCain, have put forth platforms that represent major breaks from the policies of President George W. Bush. No matter who is elected, the United States will almost certainly repeal its ban on federal funding for research on human embryonic stem cells using fresh cell lines. The new president will endorse mandatory reductions in greenhousegas emissions and work with Congress to enact meaningful climate legislation. And new leadership appointments at key agencies can 